(figured from the U.S. P. tabjes) on which are marked the averages (from Table I) which I obtained by actual experiment. Table 3 gives the shrinkage and true volume percent of alcohol when 93 percent alcohol is mixed with water in the proportions which should form various strengths of alcohol.

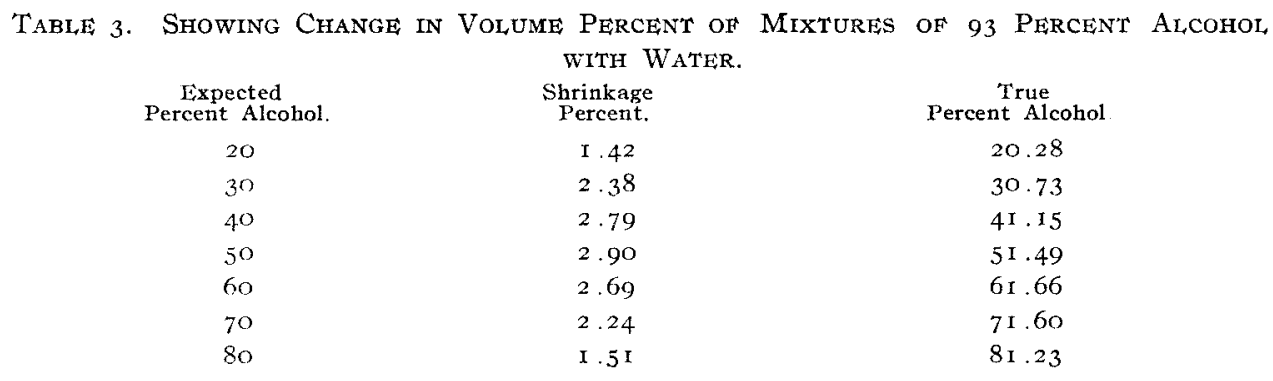

\title{
A NOTE ON A VERY OLD SPECIMEN OF PEPSIN.
}

BX I. E. WARREN.

An occasion recently arose to examine some rather old pharmaceutical preparations which were claimed to contain pepsin. Since the specimens were of unknown age (but known to be at least about 9 years old) the question arose as to the proper method to be used for making the test for proteolytic power. Since it was not the object of these tests to determine whether the preparations contained pepsin conforming to the present U. S. P. standards, and as the laboratory constant temperature bath was in use for other experiments at $40^{\circ} \mathrm{C}$. and was to be so employed for a long period, it was decided to use this temperature according to the method prescribed by the U. S. Pharmacopoeia of 1890 for the valuation of pepsin. In brief, the method consists in digesting ten grammes of moist egg albumen for six hours at a temperature of from 38 to $40^{\circ} \mathrm{C}$. with Ioo Cc. of 0.2 percent hydrochloric acid which contains $0.0035 \mathrm{Gm}$. of pepsin.

As some of the preparations to be tested (tablets) had been in the laboratory for a number of years the question of the stability of pepsin had to be considered. It chanced that a very old specimen of pepsin and. another which had been received ten years before were in stock. It seemed worth while to compare the proteolytic activity of the two old specimens with a specimen of pepsin of recent purchase, using the assay method outlined above as employed on the other pepsin preparations.

The history of the old specimen was not positively established but it is believed to have been prepared by Mr. F. S. Hereth. The label bore the statement that it had been prepared during the months of October and November, I880. Consequently at the time of this test (July), its age was probably nearly thirtynine years. Unfortunately its initial proteolytic strength was not known, but since the methods for preparing pepsin were not so refined four decades ago as now, it is probable that the specimen was not of I to 3000 value as is now required by the standards of the U. S. Pharmacopoeia. So far as the evidence could be ascertained the specimen had been stored in a small, cork-stoppered, green-glass bottle at the temperature of the laboratory since the date of manufacture and the 
container had not often been opened. The other specimen was Armour's socalled insoluble pepsin which had been received from the manufacturers in July, 1909. Since its receipt it had been stored in its original container, a cork-stoppered bottle of amber glass, at the temperature of the laboratory. The bottle had been opened from time to time and about four-fifths of the contents used. At the time of sending the preparation, the manufacturer stated that it possessed a strength of I-30oo. The proteolytic strength was not verified at the time of the receipt of the specimen. The specimen used for comparison tests was Armour's "spongy granular, soluble" pepsin received from the manufacturer in May, rgrg. "The label claimed a strength of $\mathrm{I}-3000$ for the preparation.

The old laboratory specimen was a fine, cream-colored powder which was not noticeably hygroscopic. Its odor was not unpleasant, being similar to that of the specimen of recent purchase. Its taste was distinctly saline and somewhat bitter. The material was soluble in water, yielding a turbid solution which was strongly acid toward litmus paper. The ten-year old specimen was a greyish, somewhat lumpy powder. Its odor and taste were normal. The modern specimen was in the form of pale yellowish scales or granules.

Ash was determined by igniting a weighed quantity in a porcelain crucible, moistening the charred mass with a little ammonium nitrate solution, drying and again igniting. The very old specimen gave 48.8 percent of ash while the two more recent specimens gave, respectively, 4 . I 4 percent and 3 . OI percent of ash. As an average of several trials the proteolytic strength of the three specimens was found to be, respectively, I-500, I-2500 and I-300o.

An examination was made to determine whether the literature contained reports of examinations of pepsin as old as the oldest specimen here studied, but no records were found. That a specimen nearly thirty-nine years old should retain any proteolytic activity is considered worthy of record.

Laboratory of the american Medical Association.

\section{THE LONGEVITY OF BACTERIA IN BOTTLED COMMERCIAL SPRING WATER.}

BY MAUD MASON OBST.

The longevity of bacteria in natural waters after having been bottled for commerce does not seem to have been studied extensively. Many references are made in the literature to the longevity of significant individual bacteria in water under natural conditions. Sellards" states "Typhoid bacteria are neither harbored in lower animals, nor multiply in natural waters." Houston reports ${ }^{2}$ "Outside the animal body the $B$. coli is usually known to be a decadent organism. At $20^{\circ} \mathrm{C}$. it dies rapidly in both sea and tap water." Dunham ${ }^{3}$ found that pure waters originally free from bacteria were contaminated mostly with chromogenic bacteria. Waters polluted with soil or vegetation contained B. subtilis, B. $m y$ -

1 Sellards, "Water Bacteria," Jour. Inf. Dis. Suppl. No. 3, p. 41, 1907.

2 A. C. Houston, "Significance of B. Coli in Water," British Medical Journal, No. 2699, p. 407, Sept. I912.

${ }^{3}$ E. K. Dunham, "Value of Bacterial Examination from a Sanitary Point of View." Jour. Amer. Chem. Soc., Vol. XIX, No. 8, p. 59I, Aug. 1897. 